\title{
Molecular docking and simulation studies towards exploring antiviral compounds against envelope protein of Japanese encephalitis virus
}

\author{
Sunil Kumar Gupta $\cdot$ Sarita Singh $\cdot$ \\ Anuradha Nischal · Kamlesh Kumar Pant • \\ Prahlad Kishore Seth
}

Received: 27 June 2013/Revised: 18 July 2013/ Accepted: 29 July 2013/Published online: 10 August 2013

(C) Springer-Verlag Wien 2013

\begin{abstract}
Japanese encephalitis (JE) is an acute central nervous system inflammatory disease caused by the Japanese encephalitis virus (JEV). JEV is a small, enveloped, plus-strand RNA virus belonging to the genus Flavivirus. In this study, envelope protein (E) that mediates the entry of JEV into host cell has been preferred as potential molecular target for drug development. The 3-D structure of $E$ protein was designed and validated using modeler9.10 and procheck tool, respectively, and also optimized using molecular dynamics simulation. A number of lead molecules were used for computational virtual screening against JEV E protein. Three top ranked lead molecules with strong binding affinity to JEV E protein were identified based on minimum binding energy. Molecular dynamic simulation was also performed for protein-ligand complex to study the mobility of complex at various time intervals. Drug likeliness and comparative bioactivity analysis for these leads using OSIRIS Property Explorer had shown that these molecules would have the potential to act as better drug. The mycophenolate was found to be most suitable as entry inhibitor therapeutic molecule for JEV E protein, which may be considered as a potential ligand for treatment of Japanese encephalitis.
\end{abstract}

Electronic supplementary material The online version of this article (doi:10.1007/s13721-013-0040-z) contains supplementary material, which is available to authorized users.

S. K. Gupta · A. Nischal - K. K. Pant

Department of Pharmacology and Therapeutics, King George's

Medical University, Lucknow 226003, Uttar Pradesh, India

S. K. Gupta $(\bowtie) \cdot$ S. Singh · P. K. Seth

Bioinformatics Centre, Biotech Park, Sector-G,

Jankipuram, Lucknow 226021, Uttar Pradesh, India

e-mail: skgupta.res@gmail.com
Keywords Mosquito-borne flavivirus . Japanese encephalitis virus - Envelope protein . Docking $\cdot$ Molecular dynamics

\section{Introduction}

The mosquito-borne Japanese encephalitis virus (JEV) is a positive-sense single-stranded RNA virus belonging to the Flavivirus genus of the family Flaviviridae along with several other viruses including West Nile virus (WNV), Murray valley encephalitis virus (MVEV) and St. Louis encephalitis (SLEV), Tick borne encephalitis (TBEV), Yellow fever virus (YFV) and Dengue virus (DENV). Japanese encephalitis virus is the prototypic member of JEV serocomplex of flaviviruses. It consists of eight virus species of which four viruses (Japanese encephalitis virus, Murray Valley encephalitis virus, St. Louis encephalitis virus and West Nile virus) have been consistently associated with encephalitis in cases of human infection. JEV is the sole etiologic agent of Japanese encephalitis (JE), which is reported mostly in human being in the form of frequent epidemics. JEV is transmitted by Culex mosquitoes between wild and domestic birds and pigs. Mosquitoes are vectors as well as a crucial intermediate replicative host for the normal enzootic cycle through birds and pigs, which are the primary hosts. Pigs are amplifying hosts with no evident signs of infection. The virus is transmitted by the infected mosquito bite to humans, which serve as a deadend host due to the short-duration low viraemia in man (Endy and Nisalak 2002). The symptoms of JE typically include fever and headache, but other incapacitating manifestations also usually result and frequently involve in neurological complications, including brain damage. Since the isolation of this virus in Japan in 1935, it has spread 
worldwide becoming a major public health problem. JE has a major impact in eastern and southern Asia, causing 30,000-50,000 symptomatic cases and $\sim 10,000$ deaths annually. Recently, JEV has expanded its geographical range into previously non-endemic areas, such as Australia and Pakistan (Mackenzie et al. 2002; Igarashi et al. 1994). With several billion people at risk in India, China and South-East Asia, JE represents an international emerging disease of significant concern (Hurk et al. Hurk et al. 2009).

The JEV genome is single-stranded positive-sense RNA of approximately $11 \mathrm{~kb}$ in length and contains both $5^{\prime}$ and $3^{\prime}$ untranslated regions (Vrati 2000). Translation of the genome generates a 3,432 amino acid polyprotein that is co-translationally and post-translationally processed by the virus-encoded serine protease, NS2B/NS3, host-encoded proteases, signalase and furin to produce the three structural proteins (C, prM/M and E) and seven nonstructural proteins (NS1, NS2A, NS2B, NS3, NS4A, NS4B and NS5). The structural proteins constitute the viral particle while the nonstructural proteins are involved in viral RNA replication, virus assembly, and modulation of the host cell responses (Lindenbach et al. 2007). The envelope proteins are the major structural protein, responsible for cellular attachment and possess a hydrophobic loop that mediates fusion of viral and host membranes. Infection by Japanese encephalitis virus is initiated by fusion between the viral membrane and the host membrane. The fusion process is mediated by the Japanese encephalitis virus $\mathrm{E}$ protein in a $\mathrm{pH}$-dependent manner (Stiasny and Heinz 2006). The Japanese encephalitis virus $\mathrm{E}$ protein consists of three domains: central domain I, extended fingerlike domain II, and immunoglobulin-like domain III (Modis et al. 2004; Luca et al. 2012). A similar three-domain organization is also found in the E proteins of Dengue virus, tick-borne encephalitis virus (Rey et al. 1995) and WNV (Kanai et al. 2006; Nybakken et al. 2006).

In the present scenario, there is no specific treatment against JEV strains. Few vaccines are available but they cannot treat all strains of JEV, so further studies are require for the proper evaluation and their use in treating JEV infections. The available structural data open up a new avenue for identifying antiviral agents active against early steps of JEV infection. Inhibition of enveloped viruses at the stage of viral entry provides a route for therapeutic intervention, as evidenced by the peptidic HIV entry inhibitor enfuviritide (T-20) (Kilby et al. 1998; Starr-Spires and Collman 2002). Other peptides have demonstrated activity against retroviruses in vitro (Eckert and Kim 2001; Root et al. 2001) and paramyxoviruses (Yao and Compans 1996; Young et al. 1997). Hrobowski and coworkers have identified peptide inhibitors of dengue virus and WNV infectivity using a physiochemical algorithm (Hrobowski et al. 2005). Peptidic antivirals, however, suffer from poor absorption from the gastrointestinal tract, necessitating intravenous delivery and high manufacturing costs, making it impractical to treat most vulnerable patients. We, therefore, explored the development of non-peptidic small molecules to inhibit JEV entry through computational study. In the present study, conserved E protein sequence has been identified from five genotypes of Japanese encephalitis virus and 3-D model of envelope protein (E) was designed and validated. The model displayed several meaningful features such as secondary structure, RMSD value and conserved residues engaged in nonbonded interaction. Study of surface topography for predicted 3-D model provided a clue for interaction with inhibitor molecules to inhibit the virus activity. Appropriate ligand molecule has been identified through virtual screening approach. Protein and ligand interactions were studied using molecular docking, and potential ligand molecule has been validated through ADMET property. We also employed hybrid quantum mechanics/molecular mechanics (QM/MM) molecular dynamics (MD) simulations to study the fine points of $\mathrm{E}$ protein interaction and to determine binding free energy of $E$ protein complexes with inhibitor.

With cutting edge technologies of computational approach and biomedical science at hand, the future bears hope for a breakthrough in JEV drug discovery. The scientific community all over the world has been awakened by the recent re-emergence of the encephalitis diseases, as it has now become a global problem. A considerable percentage of the JEV outbreaks occur in tropical countries like India, Pakistan, Indonesia and Brazil, among others, where large masses are living below the poverty line. It is remarkable that few successful antiviral have been developed against the JEV, but the challenges ahead are clear. New structural insights into the JEV life cycle and viral interactions with cellular molecules and antibodies provide great opportunities for identifying new classes of inhibitors. The ability to obtain high-resolution structures of viral components and inhibitory compounds using computational approach suggests that powerful structure-based approaches could rapidly focus the development of highly efficacious compounds (Singh et al. 2013; Gupta and Misra 2013).

\section{Materials and methods}

2.1 Protein sequence retrieval, alignment and template selection

Envelope protein of JEV has significant sequence information at NCBI public database (http://www.ncbi.nlm.nih. 
gov/Proteins/); total 690 sequences were identified and retrieved. The alignments of $\mathrm{E}$ protein sequences were generated with the help of Clustal X (1.81) program (Thompson et al. 1997) and pairwise genetic distances were estimated with the program MEGA v3.0 (Kumar et al. 2001). The phylogenetic analysis was performed using PHYLIP (phylogenetic inference program) package (version $3.57 \mathrm{c}$ ), with the neighbor-joining (NJ) and maximum parsimony (MP) methods. For NJ, a distance matrix calculated from the aligned sequences by Kimura Two Parameter Formula (Kimura 1980) was used, and a weight of four for transitions versus one for transversion was selected. In MP, in order to obtain the most parsimonious tree, the heuristic algorithm was performed; and for determining the reliability of tree topology, bootstrap analysis was carried out on 1,000 replicas. Bootstrap resampling technique was then used to further evaluate the reliability of the bootstrap analysis with a confidence value of 0.95 (95\%). Conserved E protein sequence (Accession No-AAB23697) was identified through multiple sequence alignment and cluster analysis. The complete protein sequence of conserved $\mathrm{E}$ protein of JEV was retrieved in FASTA format. For identification of similar sequences, BLAST program (http://www.ncbi.nim.nih.gov/blast, Altschul et al. 1990) was used against the non-redundant (nr) protein sequences data. The BlastP was performed for homology search of structurally similar sequences with the Protein Data Bank (http://www.rcsb.org).

\subsection{Prediction of 3-D structure via homology modeling}

Homology modeling is a theoretical method that is used to predict the structure of a sequence with an accuracy that is comparable to the best results achieved experimentally. The modeled protein quality is extremely dependent on the identity between the target and template proteins. The crystal structure of the West Nile virus envelope glycoprotein was available (PDB: 2I69) and used as template structure to generate 3-D model for E protein of JEV. The $\mathrm{X}$-ray 3-D structure of template was retrieved from PDB (www.rcsb.org/pdb/). The database has X-ray and NMR solved structures of proteins. The 3-D structure of target protein was generated by Modeller9.10 (Sali and Blundell 1993) tool using homology modeling approach. Visualization of predicted 3-D structure was done using Swiss Pdbviewer v 4.0.1 (http://spdbv.vital-it.ch/) and Rasmol tools.

\subsection{Evaluation and validation of the 3-D structure}

A highly reliable model is quite essential for structurebased drug designing. PROCHECK, ProSA, ProQ (Laskowski et al. 1993; Wiederstein and Sippl 2007; Wallner and Elofsson 2003) and Profile 3-D (Eswar et al. 2008) are efficient tools for evaluating protein 3-D model quality. PROCHECK checked for valid stereochemistry and ProSA optimized to find native structure compatibility. ProQ, a neural network-based predictor based on a number of structural features, predicts the quality of a protein model. Profile 3-D checks the DOPE compatibility of each residues of target sequence with respect to template sequence. The target and template DOPE profiles were plotted. The root mean square deviation (RMSD) of each atoms of the predicted model with respect to the template structure was assessed using superpose command (Eswar et al. 2008; Sali and Blundell 1993). Energy minimization was performed by Gromos96 (Christen et al. 2005) implemented via Swiss-pdb viewer (Guex et al. 2009). The overall stereo chemical quality of the protein and the amino acid residues in the allowed, disallowed region and overall G-factor were assessed by Ramachandran plot analysis. The structural superimposition of the template and predicted structure of E protein of JEV was performed using SuperPose server (http://wishart.biology.ualberta.ca/SuperPose/). The structures were visualized using Swiss Pdbviewer v 4.0.1 and UCSF Chimera (http://www.cgl.ucsf.edu/chimera/). Finally, the validated model was submitted to protein model database (Castrignano et al. 2006).

\subsection{Ligand selection}

Several antiviral molecules and their analogs were taken from the National Centre for Biotechnology Information (NCBI) Pub-Chem compound database as ligand molecules. These molecules were downloaded in Structure Data File (SDF) format and converted to Protein Data Bank (PDB) coordinates using Open Babel converter (http://openbabel.org). The selected ligand molecules were passed through the Lipinski filter (http://www. scfbio-iitd.res.in/software/utility/LipinskiFilters.jsp) for identifying their drug-like properties and only the molecules that passed through this filter were used for further analysis. Other properties like toxicity, solubility and mutagenesis of ligand molecules were calculated using OSIRIS Property Explorer (http://www.organic-chemistry. org/prog/peo/).

\subsection{Receptor and ligand optimization}

PDB coordinates of the E protein of JEV and ligand molecules were optimized using Gromacs 4.0 suite (Hess et al. 2008) force field analysis and UCSF Chimera (http://www. cgl.ucsf.edu/chimera/) tools, respectively. The optimized structures have minimum energy confirmation, which provided stability to the structure. These optimized receptor and ligand molecules were used for the docking study. 


\subsection{Docking setup}

Molecular docking plays a crucial role in computational drug design. Docking predicts the preferred orientation of a ligand with the binding site on a receptor. The strength of the interaction between ligand and receptor is measured in terms of experimentally defined inhibition constant $K_{\mathrm{d}}$. The binding energy of the receptor-ligand interaction can be measured by Eq. 1:

$\Delta G_{\text {bind }}=\Delta G_{\text {complex }}-\left(\Delta G_{\text {ligand }}-\Delta G_{\text {receptor }}\right)$

This relationship between $\Delta G$ and $K_{\mathrm{d}}$ is shown by Eq. 2 :

$\Delta G_{\text {bind }}=-\mathrm{RT} \ln K_{\mathrm{eq}}=-\mathrm{RT} \ln K_{\mathrm{d}}$

Automated docking was used to determine appropriate binding orientations and conformations of various inhibitors at the target site. Autodock 4.0 was used for docking of antiviral molecules with E protein of JEV, and Lamarckian Genetic Algorithm (LGA) was used to determine the globally optimized confirmation (Morris et al. 2009). Polar hydrogen atoms were added, and Kollman charge, atomic solvation parameters, and fragmental volumes were assigned to the protein using Autodock tools. The grid spacing was $0.375 \AA$ for each spacing; each grid map consisted of $60 \times 60 \times 60$ grid points, and 57.748, 57.623, and 57.694 coordinates. During each docking experiment, 20 runs were carried out. The population size was set at 150; maximum number of evaluation, 2,500,000; maximum number of generations, 27,000; rate of gene mutation, 0.02; and cross-over rate, 0.8 . The remaining parameters were set as default. A root mean square deviation (RMSD) tolerance for each docking was set at $2.0 \AA$. Every inhibitor molecule had 0.274 coefficients of torsional degrees of freedom for docking. At the end of docking, a cluster analysis was performed. For docking of each ligand, all the confirmations were clustered together and ranked by the lowest binding energy. To check the accuracy of docking result, Tripos sybyl and Patchdock tools (Schneidman et al. 2005) were also used. Protein and ligand interactions were calculated using Discovery Studio visualizer, which explained the active binding sites in receptor protein and best docked confirmation. Hydrogen bonds, $\mathrm{Pi}-\mathrm{Pi}$ interactions and other types of bonding were calculated.

\subsection{Molecular dynamic simulation setup}

Based on docking results, molecular dynamics simulations of active site E protein-ligand complexes were carried out using Gromacs 4.0 suite programs employing gromos force field (Hess et al. 2008). The complex was placed in centre of $90 \times 90 \times 90 \AA$ cubic box and solvated by SPC/E water molecules (Hess et al. 2008). The gromacs topology file for ligands was generated using the PRODRG2 server (http://davapc1.bioch.dundee.ac.uk/prodrg). The time constant for berendsen temperature coupling and berendsen pressure coupling was both set at 0.1 . The environment was set to $300 \mathrm{~K}$ and 1 bar. All of the complexes were energy minimized using steepest descent method. Further, a 20 ps position restraining simulation was carried out to restrict the movement of the protein in the simulation. For the long range electrostatic interactions, Particle Mesh Ewald (PME) electrostatic was used. The cut-off for coulomb interaction and Vander Waal interaction was set to $1.0 \mathrm{~nm}$ and $1.4 \mathrm{~nm}$, respectively. The LINCS algorithm was used for all bond constraints.

\section{Results and discussion}

The E protein, most important structural protein present on the surface of mature JEV, mediates the receptor binding and membrane fusion is a possible target for drug designing. $\mathrm{E}$ protein has significant sequence information in NCBI virus database. Total 690 sequences of $\mathrm{E}$ protein were identified and execute the phylogenetic analysis through NJ and MP method. The phylogenetic analysis of JEV E protein strains suggests that JEV is divided into five genotypes (GI-V) (Shimojima et al. 2011), which arose from its ancestor virus in the Indonesia-Malaysia region and evolved into five genotypes: GI, GII, GIII, GIV and $\mathrm{GV}$, out of which GIV and GV are the most divergent which remained confined to the Indonesia-Malaysia region. GI, GII and GIII are the most recent genotypes spread across Asia (Diagana et al. 2007). Through phylogeny one conserved E protein sequence (accession number: AAB23697) has been identified and used for further study and assumed that the inhibitor molecule which inhibits the activity of E protein might be able to block other $\mathrm{E}$ proteins in the genotypes (I-V).

\subsection{Tertiary structure of E protein}

The complete protein sequence of JEV $E$ protein (AAB23697) recognized via phylogeny was used in the study. The length of $\mathrm{E}$ protein was 500 amino acid residues and originated from Japan. The Protein BLAST program for $\mathrm{E}$ protein sequence was executed and hits provided $77 \%$ similarity with the target protein (Fig. 1). E protein sequence was used to generate the 3-D structure using known X-ray 3-D structure 2I69 as template. Total three models were generated by Modeler 9.10, and free energy of 3-D structures of $\mathrm{E}$ protein and template was evaluated. Only the 3rd model was thermodynamically stable and, therefore, selected for further refinement and validation. 
Fig. 1 Structure-based sequence alignment of WNV E protein (PDB ID: 2I69) as template structure with JEV E protein as target through Clustal-X. Asterisks indicates a single fully conserved residue; colon indicates that one of the strong amino acid groups is conserved; dot indicates conservation between groups of weakly similar properties

\author{
E_protein_JEV \\ 2) 69 _wNV \\ E_protein_JEV \\ 2) 69 _wNV \\ E_protein_JEV \\ 2) 69 _wNV \\ E_protein_JEV
2 I 69 _WNV \\ E_protein_JEV \\ 2) 69 _WNV \\ E_protein_JEV \\ 2) 69 _wNV \\ E_protein_JEV \\ 2) $\overline{\mathrm{I}} 69$ _WNV \\ E_protein_JEV \\ $2 \bar{I} 69$ WNV \\ E_protein_JEV \\ 2) 69 _WNV
}

FNCLGMGNRDFIEGASGATWVDLLEGDSCLTIMANDKPTLDVRMINIEASQLAEVRSYC 60 FNCLGMSNRDELEGVSGATWVDLVLEGDSCVTIMSKDKPTIDVKMMNMEAANLAEVRSYC 60

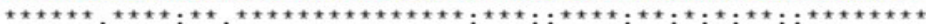

YHASVTDISTVARCPTTGEAHNEKRADSSYVCKOGETDRGWGNGCGLEGKGSIDTCAKFS 120 YLATVSDLSTKAACPTMGEAHNDKRADPAFVCRQGVVDRGWGNGCGLFGKGSIDTCAKFA 120

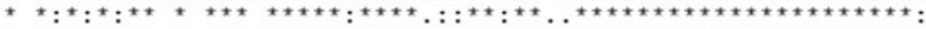

CTSKAIGRTIQPENIKYEVGIFVHGTTTSENHGNYSAQVGASQAAKETITPNAPSITLKL 180 CSTKAIGRTILKENIKYEVAIFVHGPTTVESHGNYSTQVGATQAGRESITPAAPSYTLKL 180

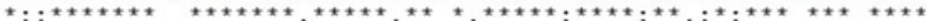

GDYGEVTLDCEPRSGLKTEAFYVMTVGSKSELVHREWEHDIALPWTSPSSTAWRNRELIM 240 GEYGEVTVDCEPRSGIDTNAYYVMTVGTKTFLVHRENEMDLNLPWSSAGSTVWRNRETLM 240

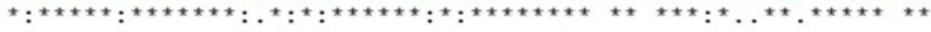

EFEEAHATKQSVVALGSQEGGLHQALAGAIVVEYSS-SVKLTSGHLKCRLKMDKLALKGT 299 EEEEPHATKQSVIALGSOEGALHOALAGAIPVEESSNTVKLTSGHLKCRVKMEKLQLKGT 300

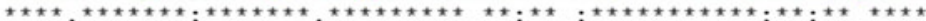

TYGNCTEKESFAKNPADTGHGTVVIELSYSGSDGPCKIPIVSVASLNDNTPVGRLVTVNP 359 TYGVCSKAFKFLGTPADTGHGTVVLELYTGTDGPCKVPISSVASLNDLTPVGRLVTVNP 360

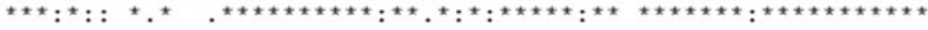

FVATSSANSKVLVEMEPPFGDSYIVVGRGDKQINHHWHKAGSTLGKAFSTTLKGAQRLAA 419 FVSVATANAKVLIELEPPEGDSYIVVGRGEQQINHHWHKSGSS--------------- 403

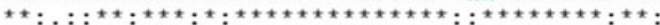

LGDTAWDEGSIGGVENSIGKAVHQVEGGAFRTLEGGMSWITQGLMGALLLWMGVNARDRS 479 IALAFLATGGVLVFLATNVHA 500

\subsection{Validation of predicted structure}

The model was subjected to validation using PROCHECK server. Ramachandran plot shows that $89.0 \%$ residues are in most favored region. According to Ramachandran plot, a good quality model will be expected to have over $90 \%$ residues in core region. Therefore, predicted model was undergone for model optimization. Refine model was subjected to further Ramachandran plot analysis and shows that $90.2 \%$ residues are in most favored region, $8.9 \%$ are in additional allowed region and only $0.2 \%$ residues are present in disallowed region (Fig. 2). Thus, the final model was validated as good quality model whose 3-D coordinates were viewed via Rasmol and UCSF Chimera tool and it depicts beta sheets rich structure. The quality of model was also assessed by comparing predicted structure to experimentally solved structure via superimposition and atoms root mean square deviation (RMSD) assessment. A model can be considered as reliable or accurate when its RMSD is $<3-4 \AA$ (accurate $\leq 2 \AA$ reliable $\geq 4 \AA$ ) (Anwar 2009). Consequently, superimposition of the template crystal structure of the West Nile virus envelope glycoprotein with predicted structure of $\mathrm{E}$ protein of JEV was executed by SuperPose tool. The weighted RMSD between predicted structure of E protein and template was $2.74 \AA$; therefore, it appears to be an accurate model. With these evaluations, E protein of JEV 3-D model was valid enough for high throughput virtual screening (VHTS) for designing

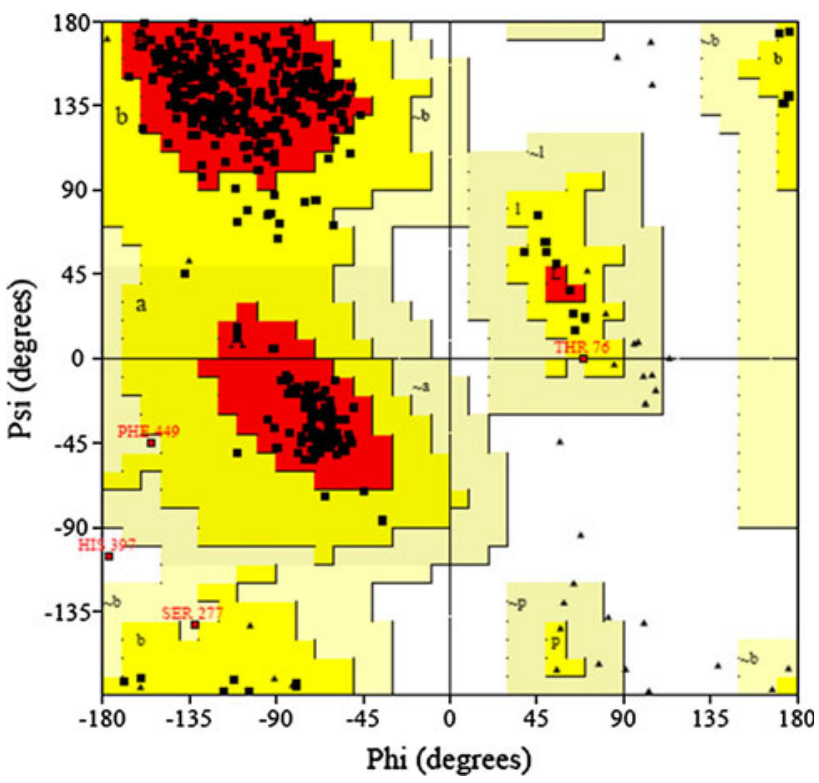

Fig. 2 Ramachandran plot of JEV E protein illustrated $90.2 \%$ residues in most favored region and $8.9 \%$ in additional allowed regions

potential antiviral drug. The structure was deposited in the protein model database and the structure was accepted with less than $2 \%$ stereo-chemical check failures. The PMDB ID of the JEV E protein 3-D model is PM0078263 (Fig. 3).

Three domains were identified in the JEV $\mathrm{E}$ protein structure based on structural homology and Pfam search. 
Fig. 3 Ribbon diagram of the modeled Japanese encephalitis virus $\mathrm{E}$ protein showing three domains, i.e., $D I, D I I$ and $D I I I$ highlighted with circles. The red square is illustrating the active pocket

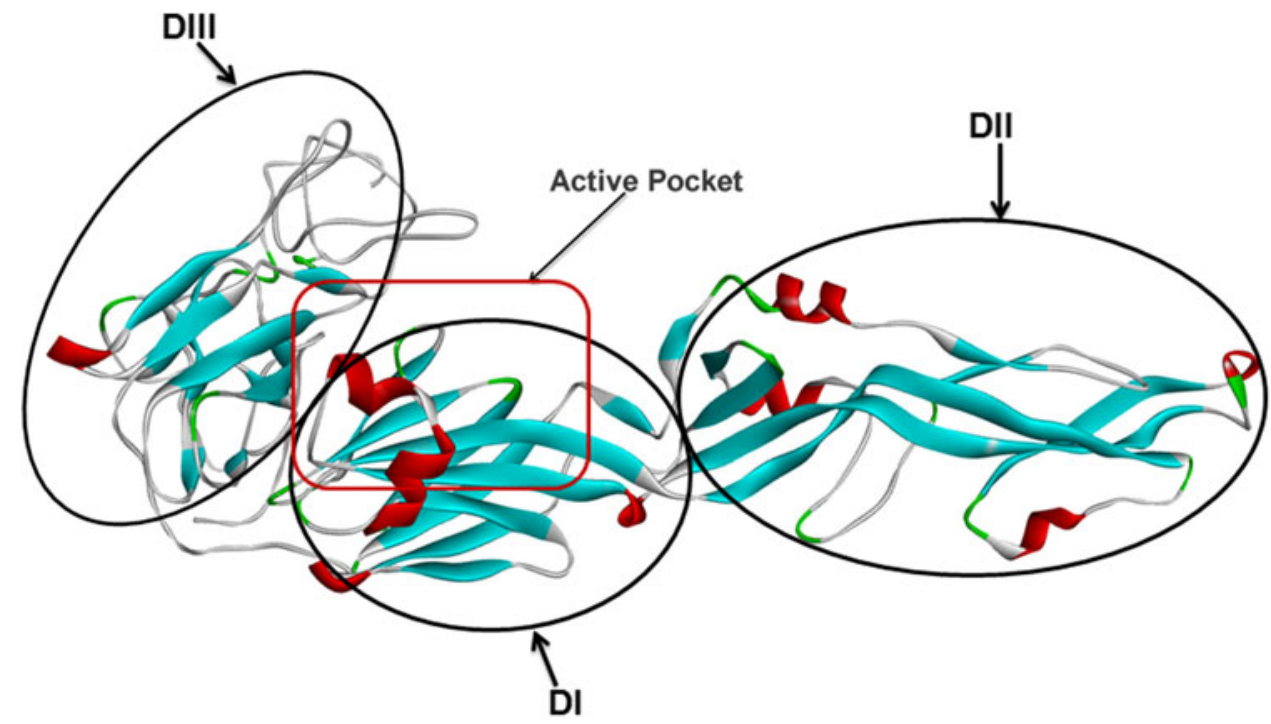

Flavivirus glycoprotein, central and dimerization domains with InterPro entry number IPR011998 span from residue 1-299. Residues 1-52, 63-137, 138-223 constitute domain I and residues 53-62, 404-500 constitute domain II. Flavivirus glycoprotein, immunoglobulin-like domain with InterPro entry IPR014756, was located from residues 291-405. This domain was represented as domain III (Fig. 3) of JEV E protein. Active pocket which is important for ligand binding was identified in the interface of domain I and III via CASTp server (Dundas et al. 2006). The amino acid residues Gly27, Asp28, Met45, Ile46, Asn47, Ile48, Lys279, Leu280, Thr281 and Ser282 were predicted as active pocket residues in JEV E protein. Multiple sequence alignment of JEV envelope protein with other flavivirus strains present at Uniprot had revealed that similar active pockets can be found in other JEV, YFV and DENV. Analysis of JEV 3-D model in Autodock 4.0 confirmed these residues as important for ligand binding.

\subsection{Screening and optimization of inhibitors}

The E protein of JEV has been reported to play a major role in the virus life cycle. Therefore, antiviral molecules were required to block the virus infection. 175 lead molecules were selected from the PubChem compound database as ligand molecules. Out of 175 molecule, 120 lead molecules did not follow the 5 Lipinski rules, i.e., not more than 5 hydrogen bond donors, not more than 10 hydrogen bond acceptors, molecular weight not $>500 \mathrm{Da}$, and an octanolwater partition coefficient $\log \mathrm{P}$ of not more than 5 (Oprea et al. 2001) or those that had a polar surface area of $<140 \AA$ Á, as suggested by Ghose et al. (1999) were discarded. After this filtration step, only 55 lead molecules remained that were used for further analysis. These molecules were also separated into nine clusters on the basis of their analogs. Nearly, $40 \%$ of drug candidates fail in clinical trials due to poor ADME (absorption, distribution, metabolism, and excretion) properties. Thus, an important aspect of drug discovery is to avoid compounds not having drug likeliness and good ADME property. So to streamline the virtual screening drug likeliness and ADME properties of the 55 compounds were predicted using OSIRIS Property Explorer. Details of the selected molecules and their physiochemical properties, toxicity risk, mutagenesis and solubility, drug-likeliness, etc. of ligand molecules are given in Table 1 and Supplementary Table 1. The PDB coordinates of the $\mathrm{E}$ protein (as receptor) and lead molecules (as ligand) were optimized using Gromacs (Hess et al. 2008) and Chimera tools (http://www.cgl.ucsf.edu/ chimera/) to attain their minimum energy confirmation and obtain a thermodynamically stable structure. Subsequently, the receptor and ligands were subjected to docking using Autodock 4.0.

\subsection{Docking study and interaction analysis}

Autodock 4.0 was used to dock inhibitors to identify the active entities and determine the active binding sites in target proteins. Lamarckian Genetic Algorithm (LGA) for docking was used with defined parameters for determining the docking performance. The output of molecular docking was clustered to determine the binding free energy (BE) and optimal docking energy conformation that is considered as the best docked structure, as well as to elucidate their binding state in the receptor. BE for each docking was calculated using a semi-empirical free energy force field 
Table 1 Detail of novel lead molecules obtained through virtual high throughput screening

\begin{tabular}{|c|c|c|c|c|c|c|c|c|c|}
\hline S. no. & Ligand name & & CID no. & $\begin{array}{l}\text { Molecular } \\
\text { weight } \\
(\mathrm{g} / \mathrm{mol})\end{array}$ & $\begin{array}{l}\text { Molecular } \\
\text { formula }\end{array}$ & $\begin{array}{l}\text { X-log value } \\
\text { P }\end{array}$ & $\begin{array}{l}\text { H-bond } \\
\text { donor }\end{array}$ & $\begin{array}{l}\text { H-bond } \\
\text { acceptor }\end{array}$ & $\begin{array}{l}\text { Topological } \\
\text { polar surface } \\
\text { area }\end{array}$ \\
\hline 1. & Mycophenolate & 1 & 446541 & 320.3371 & $\mathrm{C}_{17} \mathrm{H}_{20} \mathrm{O}_{6}$ & 3.2 & 2 & 6 & 93.1 \\
\hline 2. & Triaryl pyrazoline & 2 & 11646325 & 366.8639 & $\mathrm{C}_{20} \mathrm{H}_{15} \mathrm{ClN}_{2} \mathrm{OS}$ & 5 & 0 & 3 & 60.9 \\
\hline 3. & Beta-L-fucose & 3 & 444863 & 164.15648 & $\mathrm{C}_{6} \mathrm{H}_{12} \mathrm{O}_{5}$ & -2.1 & 4 & 5 & 90.2 \\
\hline 4. & $N$-acetyl-D-glucosamine & 4 & 24139 & 221.2078 & $\mathrm{C}_{8} \mathrm{H}_{15} \mathrm{NO}_{6}$ & -1.7 & 5 & 6 & 119 \\
\hline \multirow[t]{20}{*}{5.} & \multirow[t]{20}{*}{ Castanospermine } & 5 & 54445 & 189.209 & $\mathrm{C}_{8} \mathrm{H}_{15} \mathrm{NO}_{4}$ & -2.2 & 4 & 5 & 84.2 \\
\hline & & 6 & 451465 & 293.31506 & $\mathrm{C}_{15} \mathrm{H}_{19} \mathrm{NO}_{5}$ & 0 & 3 & 6 & 90.2 \\
\hline & & 7 & 451521 & 283.27718 & $\mathrm{C}_{13} \mathrm{H}_{17} \mathrm{NO}_{6}$ & -0.6 & 3 & 7 & 103 \\
\hline & & 8 & 3000231 & 307.34164 & $\mathrm{C}_{16} \mathrm{H}_{21} \mathrm{NO}_{5}$ & 0.4 & 3 & 6 & 90.2 \\
\hline & & 9 & 365176 & 173.2096 & $\mathrm{C}_{8} \mathrm{H}_{15} \mathrm{NO}_{3}$ & -1.3 & 3 & 4 & 63.9 \\
\hline & & 10 & 363391 & 231.24568 & $\mathrm{C}_{10} \mathrm{H}_{17} \mathrm{NO}_{5}$ & -1.7 & 3 & 6 & 90.2 \\
\hline & & 11 & 363393 & 343.45832 & $\mathrm{C}_{18} \mathrm{H}_{33} \mathrm{NO}_{5}$ & 2.4 & 3 & 6 & 90.2 \\
\hline & & 12 & 451989 & 189.209 & $\mathrm{C}_{8} \mathrm{H}_{15} \mathrm{NO}_{4}$ & -2.2 & 4 & 5 & 84.2 \\
\hline & & 13 & 184806 & 189.209 & $\mathrm{C}_{8} \mathrm{H}_{15} \mathrm{NO}_{4}$ & -2.2 & 4 & 5 & 84.2 \\
\hline & & 14 & 451535 & 372.21112 & $\mathrm{C}_{15} \mathrm{H}_{18} \mathrm{BrNO}_{5}$ & 0.7 & 3 & 6 & 90.2 \\
\hline & & 15 & 451534 & 307.34164 & $\mathrm{C}_{16} \mathrm{H}_{21} \mathrm{NO}_{5}$ & 0.4 & 3 & 6 & 90.2 \\
\hline & & 16 & 451524 & 307.34164 & $\mathrm{C}_{16} \mathrm{H}_{21} \mathrm{NO}_{5}$ & 0.4 & 3 & 6 & 90.2 \\
\hline & & 17 & 19978366 & 230.26092 & $\mathrm{C}_{10} \mathrm{H}_{18} \mathrm{~N}_{2} \mathrm{O}_{4}$ & -2.2 & 4 & 5 & 93 \\
\hline & & 18 & 9837515 & 230.26092 & $\mathrm{C}_{10} \mathrm{H}_{18} \mathrm{~N}_{2} \mathrm{O}_{4}$ & -2.2 & 4 & 5 & 93 \\
\hline & & 19 & 125391 & 173.2096 & $\mathrm{C}_{8} \mathrm{H}_{15} \mathrm{NO}_{3}$ & -1.3 & 3 & 4 & 63.9 \\
\hline & & 20 & 22842043 & 188.22424 & $\mathrm{C}_{8} \mathrm{H}_{16} \mathrm{~N}_{2} \mathrm{O}_{3}$ & -2.5 & 4 & 5 & 90 \\
\hline & & 21 & 2592 & 189.209 & $\mathrm{C}_{8} \mathrm{H}_{15} \mathrm{NO}_{4}$ & -2.2 & 4 & 5 & 84.2 \\
\hline & & 22 & 3033824 & 295.75978 & $\mathrm{C}_{12} \mathrm{H}_{22} \mathrm{ClNO}_{5}$ & - & 4 & 6 & 90.2 \\
\hline & & 23 & 195154 & 173.2096 & $\mathrm{C}_{8} \mathrm{H}_{15} \mathrm{NO}_{3}$ & -1.3 & 3 & 4 & 63.9 \\
\hline & & 24 & 356986 & 189.209 & $\mathrm{C}_{8} \mathrm{H}_{15} \mathrm{NO}_{4}$ & -2.2 & 4 & 5 & 84.2 \\
\hline \multirow[t]{26}{*}{6.} & \multirow[t]{26}{*}{ Deoxynojirimycin } & 25 & 29435 & 163.17172 & $\mathrm{C}_{6} \mathrm{H}_{13} \mathrm{NO}_{4}$ & -2.3 & 5 & 5 & 93 \\
\hline & & 26 & 51634 & 219.27804 & $\mathrm{C}_{10} \mathrm{H}_{21} \mathrm{NO}_{4}$ & -0.6 & 4 & 5 & 84.2 \\
\hline & & 27 & 501640 & 289.41094 & $\mathrm{C}_{15} \mathrm{H}_{31} \mathrm{NO}_{4}$ & 2.1 & 4 & 5 & 84.2 \\
\hline & & 28 & 92381 & 177.1983 & $\mathrm{C}_{7} \mathrm{H}_{15} \mathrm{NO}_{4}$ & -1.9 & 4 & 5 & 84.2 \\
\hline & & 29 & 441314 & 207.22428 & $\mathrm{C}_{8} \mathrm{H}_{17} \mathrm{NO}_{5}$ & -2.6 & 5 & 6 & 104 \\
\hline & & 30 & 51577 & 207.22428 & $\mathrm{C}_{8} \mathrm{H}_{17} \mathrm{NO}_{5}$ & -2.6 & 5 & 6 & 104 \\
\hline & & 31 & 6438405 & 279.33154 & $\mathrm{C}_{15} \mathrm{H}_{21} \mathrm{NO}_{4}$ & 0.3 & 4 & 5 & 84.2 \\
\hline & & 32 & 129374 & 233.30462 & $\mathrm{C}_{11} \mathrm{H}_{23} \mathrm{NO}_{4}$ & -0.1 & 4 & 5 & 84.2 \\
\hline & & 33 & 3662391 & 397.54876 & $\mathrm{C}_{22} \mathrm{H}_{39} \mathrm{NO}_{5}$ & 1.9 & 4 & 6 & 93.4 \\
\hline & & 34 & 122618 & 147.17232 & $\mathrm{C}_{6} \mathrm{H}_{13} \mathrm{NO}_{3}$ & -1.9 & 4 & 4 & 72.7 \\
\hline & & 35 & 475537 & 303.43752 & $\mathrm{C}_{16} \mathrm{H}_{33} \mathrm{NO}_{4}$ & 2.6 & 4 & 5 & 84.2 \\
\hline & & 36 & 133177 & 277.31412 & $\mathrm{C}_{12} \mathrm{H}_{23} \mathrm{NO}_{6}$ & -3.6 & 5 & 7 & 122 \\
\hline & & 37 & 475540 & 305.41034 & $\mathrm{C}_{15} \mathrm{H}_{31} \mathrm{NO}_{5}$ & 0.3 & 4 & 6 & 93.4 \\
\hline & & 38 & 475539 & 305.41034 & $\mathrm{C}_{15} \mathrm{H}_{31} \mathrm{NO}_{5}$ & 0.8 & 4 & 6 & 93.4 \\
\hline & & 39 & 1374 & 163.17172 & $\mathrm{C}_{6} \mathrm{H}_{13} \mathrm{NO}_{4}$ & -2.3 & 5 & 5 & 93 \\
\hline & & 40 & 9822159 & 397.54876 & $\mathrm{C}_{22} \mathrm{H}_{39} \mathrm{NO}_{5}$ & 1.9 & 4 & 6 & 93.4 \\
\hline & & 41 & 475542 & 309.35598 & $\mathrm{C}_{13} \mathrm{H}_{27} \mathrm{NO}_{7}$ & -2.3 & 4 & 8 & 112 \\
\hline & & 42 & 475541 & 319.43692 & $\mathrm{C}_{16} \mathrm{H}_{33} \mathrm{NO}_{5}$ & 0.8 & 3 & 6 & 82.4 \\
\hline & & 43 & 475538 & 345.36326 & $\mathrm{C}_{16} \mathrm{H}_{24} \mathrm{FNO}_{6}$ & -0.3 & 4 & 8 & 103 \\
\hline & & 44 & 46229705 & 434.4828 & $\mathrm{C}_{22} \mathrm{H}_{30} \mathrm{~N}_{2} \mathrm{O}_{7}$ & -0.9 & 5 & 8 & 140 \\
\hline & & 45 & 46229704 & 482.5256 & $\mathrm{C}_{26} \mathrm{H}_{30} \mathrm{~N}_{2} \mathrm{O}_{7}$ & 0.9 & 5 & 8 & 140 \\
\hline & & 46 & 475543 & 365.4623 & $\mathrm{C}_{17} \mathrm{H}_{35} \mathrm{NO}_{7}$ & -0.9 & 4 & 8 & 112 \\
\hline & & 47 & 6603107 & 255.73898 & $\mathrm{C}_{10} \mathrm{H}_{22} \mathrm{ClNO}_{4}$ & - & 5 & 5 & 84.2 \\
\hline & & 48 & 72258 & 163.17172 & $\mathrm{C}_{6} \mathrm{H}_{13} \mathrm{NO}_{4}$ & -2.3 & 5 & 5 & 93 \\
\hline & & 49 & 44387838 & 163.17172 & $\mathrm{C}_{6} \mathrm{H}_{13} \mathrm{NO}_{4}$ & -2.3 & 5 & 5 & 93 \\
\hline & & 50 & 4381 & 177.1983 & $\mathrm{C}_{7} \mathrm{H}_{15} \mathrm{NO}_{4}$ & -1.9 & 4 & 5 & 84.2 \\
\hline
\end{tabular}


Table 1 continued

\begin{tabular}{|c|c|c|c|c|c|c|c|c|c|}
\hline S. no. & Ligand name & & CID no. & $\begin{array}{l}\text { Molecular } \\
\text { weight } \\
\text { (g/mol) }\end{array}$ & $\begin{array}{l}\text { Molecular } \\
\text { formula }\end{array}$ & $\begin{array}{l}X-\log \\
\text { valueP }\end{array}$ & $\begin{array}{l}\text { H-bond } \\
\text { donor }\end{array}$ & $\begin{array}{l}\text { H-bond } \\
\text { acceptor }\end{array}$ & $\begin{array}{l}\text { Topological } \\
\text { polar surface } \\
\text { area }\end{array}$ \\
\hline \multirow[t]{3}{*}{7.} & Ribavirin & 51 & 451947 & 210.19 & $\mathrm{C}_{8} \mathrm{H}_{10} \mathrm{~N}_{4} \mathrm{O}_{3}$ & -1.1 & 2 & 3 & 103 \\
\hline & & 52 & 452721 & 226.1894 & $\mathrm{C}_{8} \mathrm{H}_{10} \mathrm{~N}_{4} \mathrm{O}_{4}$ & -2 & 2 & 4 & 116 \\
\hline & & 53 & 127986 & 412.52364 & $\mathrm{C}_{20} \mathrm{H}_{36} \mathrm{~N}_{4} \mathrm{O}_{5}$ & 3 & 1 & 5 & 111 \\
\hline 8. & $1 H$-benzotriazole & 54 & 7220 & 119.124 & $\mathrm{C}_{6} \mathrm{H}_{5} \mathrm{~N}_{3}$ & 1 & 1 & 2 & 41.6 \\
\hline 9. & $1 H$-benzimidazole & 55 & 5798 & 118.13594 & $\mathrm{C}_{7} \mathrm{H}_{6} \mathrm{~N}_{2}$ & 1.3 & 1 & 0 & 28.7 \\
\hline
\end{tabular}

with charge-based desolvation and grid-based docking. The force field was decided on the basis of a comprehensive thermodynamic model that allows the incorporation of intermolecular energies into the predicted BE (Morris et al. 2009). It also included a charge-based method for the evaluation of desolvation. The method was designed to use a typical set of atom types. The formula for calculating semiempirical $\mathrm{BE}$ is given below:

$$
\begin{aligned}
\Delta G_{\text {binding }}= & \Delta G_{\text {vdw }}+\Delta G_{\text {elec }}+\Delta G_{\text {hbond }}+\Delta G_{\text {desolv }} \\
& +\Delta G_{\text {tors }}+\Delta G_{\text {intermol }}
\end{aligned}
$$

where $\Delta G_{\mathrm{vdw}}$ is the Vander wall or Lennard-Jones potential, $\Delta G_{\text {elec }}$ is the electrostatic factor with distance-dependent dielectric, $\Delta G_{\text {hbond }}$ is the H-bonding potential with directionality, $\Delta G_{\text {desolv }}$ is the charge-dependent variant of volume-based atomic solvation, $\Delta G_{\text {tor }}$ is the torsional energy based on the number of rotatable bonds, and $\Delta G_{\text {intermol }}$ is the intermolecular energy of protein and ligand molecules (Morris et al. 2009).

The summations were performed over all pairs of ligand and protein atoms, and the BE was calculated. Docking was also performed to determine the inhibition constant $\left(K_{\mathrm{i}}\right)$ for drug-like molecules and to calculate the RMSD value (Table 2).

Out of these 55 docked molecules, top five molecules were filtered out on the basis of binding energy. Most docked inhibitors showed maximum number of hydrogen bonds with ASP28 and MET45 amino acids. The mycophenolate (CID_446541) is showing hydrogen bond interactions with ASP28 and MET45 and Pi interaction with ASP28 and LYS279 residue of receptor (Fig. 4). The binding modes and geometrical orientation of all compounds were almost identical, suggesting that all the inhibitors occupied a common cavity in the receptor. The binding pattern of top five inhibitor (on the basis of binding energy) molecules with an active site and the hydrogen bond distance in the target protein are given in Table 3.

For confirming the accuracy of the predicted molecule, the Tripos Sybyl and Patchdock tools were also used.
Tripos Sybyl generates a genetic algorithm and calculates the binding affinity for the binding site of a target protein. The Patchdock tool is a geometry-based molecular docking algorithm to identify docking transformations, molecular shape complementarities, perform clustering and calculates the global binding energy. The clustering RMSD value has been considered as $2.0 \AA$ for this analysis. Mycophenolate showed good docking energy, i. e., $-100.143 \mathrm{kcal} / \mathrm{mol}$ with the protein and a minimum global free energy of $-43.20 \mathrm{kcal} / \mathrm{mol}$, as revealed by Tripos Sybyl and Patchdock tool, respectively (Table 4). Hence, in the present study, mycophenolate was confirmed to be an appropriate molecule using 3 docking tools, and it might be considered as potential antiviral drug candidate (Fig. 5).

\subsection{Simulation of protein-ligand complex}

The main purpose of the MD simulation studies was to investigate the positional and conformational changes of inhibitor molecule in relation to the binding site that provides insight into the binding stability. MD revealed that this molecule could efficiently activate the biological pathway without changing the conformation in the binding site of $\mathrm{E}$ protein. To evaluate the stabilities of mycophenolate-E protein complexes during the MD simulations, root mean square deviation (RMSD) was calculated with respect to the initial structures along the $3.0 \mathrm{~ns}$ (ns) trajectories (Fig. 6). The trajectories indicated the stabilization of the receptor on the binding of mycophenolate in the active site after $1.0 \mathrm{~ns}$ in system with a mean RMSD value of $2.5 \mathrm{~nm}$. In addition, the stability of the system also proved the credibility of the docking results. Total energy of the most active conformation of the molecule was $-8.79801 \mathrm{e}+06 \mathrm{~kJ} / \mathrm{mol}$. The temperature and pressure do not have any effect on the conformation of the structure. The hydrogen bonds formed between the protein and inhibitor after simulation were mostly concentrated in the activation loop region of the protein which is responsible for the catalytic machinery and substrate binding. This is explicitly understood from the above observation. 
Table 2 Binding free energies, inhibition constants and other energies of protein-ligand complex

\begin{tabular}{|c|c|c|c|c|c|c|c|c|}
\hline S. no. & Compound ID & $\Delta G_{\text {tors }}$ & $\begin{array}{l}\Delta G_{\mathrm{vd}}+\Delta G_{\mathrm{hbond}} \\
+\Delta G_{\mathrm{desolv}}\end{array}$ & $\Delta G_{\text {elec }}$ & $\Delta G_{\text {intermol }}$ & $\Delta G_{\text {binding }}$ & $\Delta G_{\text {inter }}$ & $K_{\mathrm{i}}$ \\
\hline 1. & 446541 & +2.20 & -5.73 & -2.84 & -8.57 & -7.01 & -1368.38 & 7.22 \\
\hline 2. & 24139 & +1.65 & -5.64 & -0.53 & -6.16 & -6.19 & -1368.76 & 29.08 \\
\hline 3. & 444863 & +1.10 & -5.27 & -0.35 & -5.63 & -5.69 & -1369.20 & 67.23 \\
\hline 4. & 11646325 & +0.82 & -5.60 & -0.08 & -5.68 & -5.46 & -1369.33 & 99.25 \\
\hline 5. & 54445 & +1.10 & -5.16 & -2.04 & -7.20 & -6.01 & -1369.73 & 39.43 \\
\hline 6. & 451465 & +1.65 & -5.59 & -1.24 & -6.83 & -5.89 & -1369.01 & 48.50 \\
\hline 7. & 451521 & +1.65 & -5.34 & -1.73 & -7.07 & -5.76 & -1369.23 & 60.19 \\
\hline 8. & 3000231 & +1.65 & -4.74 & -1.91 & -6.65 & -5.60 & -1369.05 & 77.91 \\
\hline 9. & 365176 & +0.82 & -3.74 & -1.56 & -5.31 & -4.31 & -1368.35 & 687.74 \\
\hline 10. & 363391 & +1.37 & -3.29 & -1.77 & -5.06 & -4.44 & -1368.41 & 552.06 \\
\hline 11. & 363393 & +3.57 & -5.79 & -1.60 & -7.39 & -4.75 & -1367.92 & 332.23 \\
\hline 12. & 451989 & +1.10 & -4.83 & -1.46 & -6.29 & -5.32 & -1369.33 & 125.30 \\
\hline 13. & 184806 & +1.10 & -4.14 & -1.54 & -5.68 & -4.61 & -1368.67 & 415.28 \\
\hline 14. & 451534 & +1.65 & -5.37 & -1.92 & -7.29 & -5.94 & -1369.34 & 44.31 \\
\hline 15. & 451524 & +1.65 & -5.71 & -1.59 & -7.30 & -5.92 & -1369.48 & 46.10 \\
\hline 16. & 19978366 & +1.10 & -5.74 & -1.81 & -7.55 & -6.45 & -1369.37 & 18.79 \\
\hline 17. & 9837515 & +1.10 & -5.06 & -2.11 & -7.18 & -6.23 & -1369.99 & 27.06 \\
\hline 18. & 125391 & +0.82 & -4.21 & -1.59 & -5.80 & -4.38 & -1368.44 & 620.42 \\
\hline 19. & 22842043 & +1.10 & -3.67 & -3.03 & -6.70 & -5.38 & -1369.45 & 114.81 \\
\hline 20. & 2592 & +1.10 & -4.44 & -1.67 & -6.11 & -5.25 & -1368.89 & 142.92 \\
\hline 21. & 195154 & +0.82 & -4.30 & -1.91 & -6.21 & -5.64 & -1369.07 & 73.45 \\
\hline 22. & 356986 & +1.10 & -5.76 & -1.72 & -7.48 & -6.29 & -1370.02 & 24.58 \\
\hline 23. & 29435 & +1.37 & -4.70 & -1.49 & -6.19 & -5.66 & -1368.81 & 71.18 \\
\hline 24. & 51634 & +2.20 & -4.23 & -1.68 & -5.91 & -4.31 & -1367.75 & 692.98 \\
\hline 25. & 501640 & +3.57 & -5.29 & -2.02 & -7.32 & -4.56 & -1367.87 & 457.89 \\
\hline 26. & 92381 & +1.37 & -4.79 & -2.02 & -6.81 & -5.90 & -1369.69 & 47.64 \\
\hline 27. & 441314 & +2.20 & -3.83 & -1.64 & -5.47 & -5.17 & -1368.72 & 163.01 \\
\hline 28. & 51577 & +2.20 & -4.47 & -1.61 & -6.07 & -4.75 & -1368.44 & 328.37 \\
\hline 29. & 6438405 & +2.20 & -5.71 & -1.59 & -7.31 & -5.68 & -1369.05 & 68.19 \\
\hline 30. & 129374 & +2.47 & -4.59 & -1.37 & -5.96 & -4.22 & -1368.17 & 803.89 \\
\hline 31. & 3662391 & +3.57 & -4.61 & -1.66 & -6.27 & -5.30 & -1367.62 & 129.58 \\
\hline 32. & 122618 & +0.82 & -3.55 & -1.55 & -5.10 & -4.73 & -1368.76 & 338.85 \\
\hline 33. & 475537 & +3.84 & -5.74 & -2.25 & -7.99 & -4.66 & -1368.01 & 382.45 \\
\hline 34. & 133177 & +3.29 & -3.57 & -1.26 & -4.83 & -4.02 & -1367.65 & 1.12 \\
\hline 35. & 475540 & +3.84 & -5.67 & -1.81 & -7.48 & -4.51 & -1367.54 & 495.39 \\
\hline 36. & 475539 & +3.84 & -6.09 & -1.33 & -7.41 & -5.43 & -1367.82 & 104.61 \\
\hline 37. & 1374 & +1.37 & -4.81 & -2.19 & -7.00 & -6.55 & -1369.98 & 15.85 \\
\hline 38. & 9822159 & +3.57 & -5.27 & -1.53 & -6.80 & -4.90 & -1368.02 & 257.80 \\
\hline 39. & 475542 & +3.84 & -4.34 & -0.97 & -5.31 & -4.95 & -1368.49 & 235.24 \\
\hline 40. & 475541 & +3.84 & -5.03 & -1.45 & -6.47 & -3.51 & -1366.65 & 2.69 \\
\hline 41. & 475538 & +3.29 & -4.85 & -0.74 & -5.59 & -4.28 & -1367.42 & 726.45 \\
\hline 42. & 46229705 & +4.12 & -6.69 & -2.16 & -8.85 & -5.51 & -1367.48 & 90.86 \\
\hline 43. & 46229704 & +3.84 & -5.24 & -1.26 & -6.50 & -4.35 & -1367.64 & 644.48 \\
\hline 44. & 475543 & +4.94 & -5.18 & -1.19 & -6.37 & -3.08 & -1366.37 & 5.52 \\
\hline 45. & 72258 & +1.37 & -3.62 & -1.55 & -5.17 & -4.60 & -1368.61 & 423.94 \\
\hline 46. & 44387838 & +1.37 & -3.98 & -1.66 & -5.64 & -5.24 & -1369.07 & 144.42 \\
\hline
\end{tabular}


Table 2 continued

\begin{tabular}{lrllllrrr}
\hline S. no. & Compound ID & $\Delta G_{\text {tors }}$ & $\begin{array}{l}\Delta G_{\text {vd }}+\Delta G_{\text {hbond }} \\
+\Delta G_{\text {desolv }}\end{array}$ & $\Delta G_{\text {elec }}$ & $\Delta G_{\text {intermol }}$ & $\Delta G_{\text {binding }}$ & $\Delta G_{\text {inter }}$ & $K_{\text {i }}$ \\
\hline 47. & 4381 & +1.37 & -4.07 & -1.49 & -5.55 & -4.71 & -1368.58 \\
48. & 451947 & +1.10 & -5.21 & -0.07 & -5.28 & -5.17 & -1368.39 & 162.82 \\
49. & 452721 & +1.10 & -4.09 & -0.51 & -4.60 & -4.60 & -1368.35 & 423.57 \\
50. & 127986 & +4.12 & -4.69 & -0.03 & -4.72 & -2.42 & -1366.31 & 16.77 \\
51. & 451535 & +1.92 & -6.57 & -0.37 & -6.94 & -6.32 & -1369.37 \\
52. & 6603107 & +1.65 & -5.31 & -0.24 & -5.55 & -5.69 & -1368.57 \\
53. & 5798 & +0.00 & -3.72 & -0.06 & -3.78 & -3.78 & -1367.99 \\
54. & 7220 & +0.00 & -4.47 & -0.19 & -4.66 & -4.66 & -1368.87 & 381.72 \\
55. & 501640 & +3.57 & -5.99 & -1.38 & -7.38 & -4.85 & -1367.77 & 278.10 \\
\hline
\end{tabular}

$\Delta G_{\mathrm{vdw}}$, Vander wall or Linard Jones potential factor of binding free energy (kcal/mol); $\Delta G_{\text {elec }}$, Electrostatic factor of binding free energy (kcal/ mol); $\Delta G_{\text {hbond }}$, H-bonding factor of binding free energy $(\mathrm{kcal} / \mathrm{mol}) ; \Delta G_{\text {desolv }}$, Desolvation factor of binding free energy $(\mathrm{kcal} / \mathrm{mol}) ; \Delta G_{\text {tors }}$,

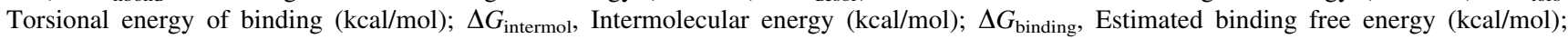
$\Delta G_{\text {inter }}$, Gibbs free energy of binding ( $\left.\mathrm{kcal} / \mathrm{mol}\right) ; K_{\mathrm{i}}$, Inhibition constant [uM (micromolar)]
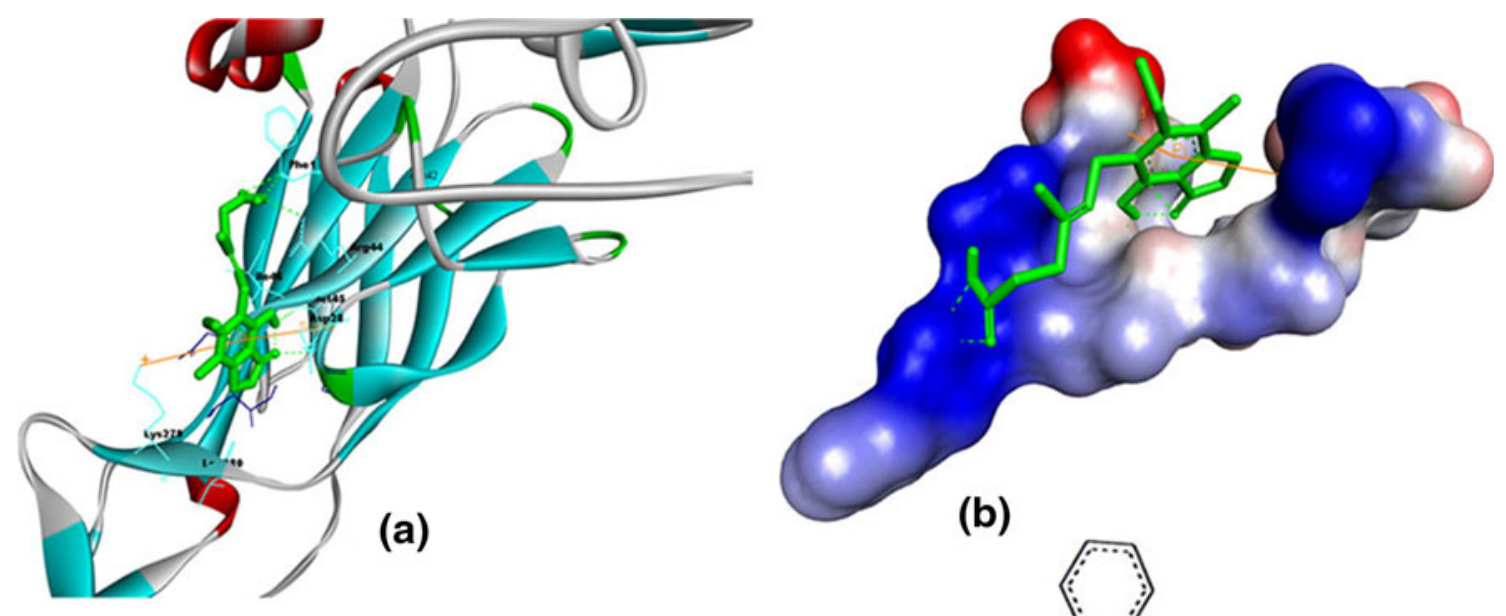

(b)

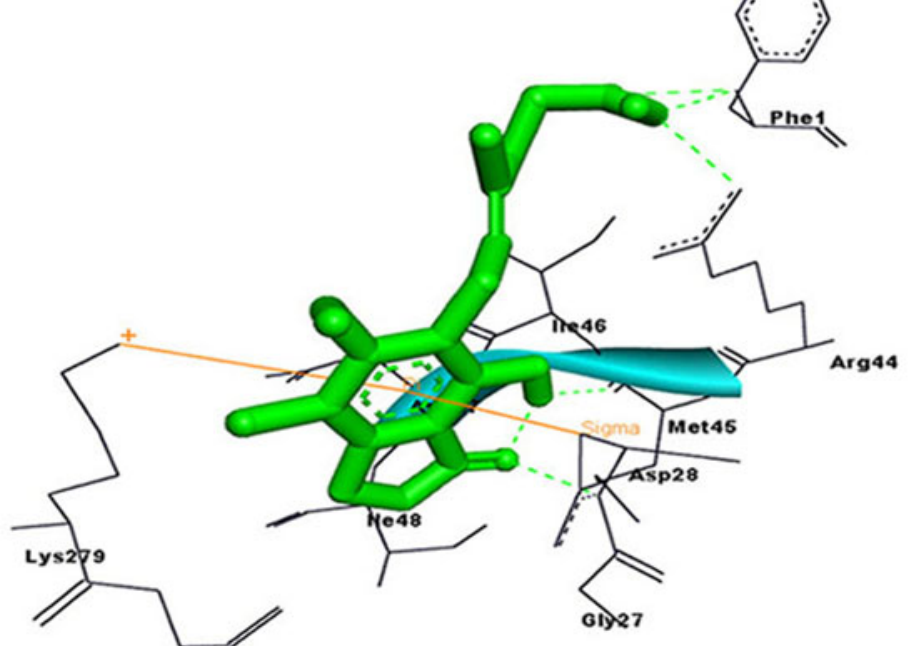

(c)

Fig. 4 Molecule interaction of JEV E protein with mycophenolate (CID_446541). a-c is showing various display style of protein-ligand complex, illustrating hydrogen bond interactions with ASP28 and MET45 and Pi bond interaction with ASP28 and LYS279 
Table 3 Binding pattern, docking energy and hydrogen bonding of five best inhibitor molecules

\begin{tabular}{|c|c|c|c|c|}
\hline S. no. & Compound ID & Binding energy & Docking energy & Hydrogen bonding $(\AA)$ \\
\hline 1. & 446541 & -7.01 & -9.21 & 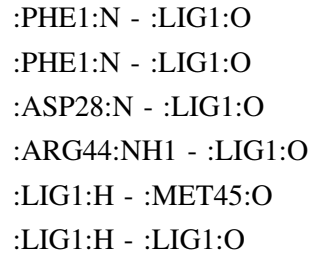 \\
\hline 2. & 1374 & -6.55 & -7.92 & 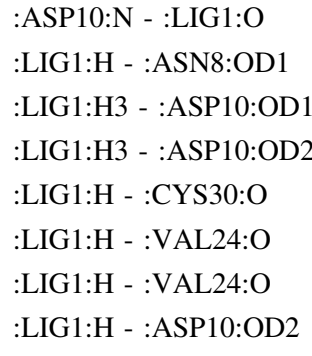 \\
\hline 3. & 19978366 & -6.45 & -7.55 & 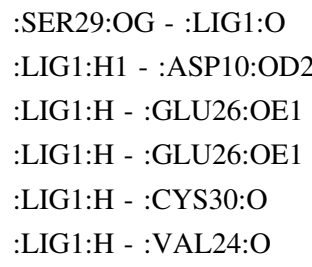 \\
\hline 4. & 356986 & -6.29 & -7.58 & 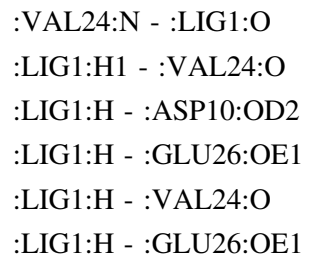 \\
\hline 5. & 451535 & -6.32 & -8.25 & $\begin{array}{l}\text { :ASP28:N - :LIG1:O } \\
\text { :ILE48:N - :LIG1:O } \\
\text { :LIG1:H - :MET45:O } \\
\text { :LIG1:H - :ILE46:O } \\
\text { :LIG1:H - :MET45:O } \\
\text { :LIG1:H - :LEU280:O }\end{array}$ \\
\hline
\end{tabular}

Table 4 Comparison of docking scores for three best lead molecules using several docking tools

\begin{tabular}{llccc}
\hline S. no. & PubChem ID and name & $\begin{array}{l}\text { Autodock 4.0 } \\
(\mathrm{kcal} / \mathrm{mol})\end{array}$ & $\begin{array}{c}\text { Tripos Sybyl } \\
(\mathrm{kcal} / \mathrm{mol})\end{array}$ & $\begin{array}{l}\text { Patchdock } \\
(\mathrm{kcal} / \mathrm{mol})\end{array}$ \\
\hline 1. & CID 446541 (Mycophenolate) & -7.01 & -100.143 \\
2. & CID 1374 (Deoxynojirimycin) & -6.55 & -68.320 & -43.20 \\
3. & CID 19978366 (Castanospermine) & -6.45 & -63.281 & -34.96 \\
\hline
\end{tabular}

\section{Conclusion}

The main objective of this study was to identify suitable ligand molecules against envelop protein for the entire genotypes (I-V) of JEV. Consequently, the 3-D model of conserved envelope protein of Japanese encephalitis virus was designed and validated. The model displayed various significant features such as secondary structure, RMSD value and conserved residues engaged in non-bonded interaction. The model described that it has $90.2 \%$ residues in core region in Ramachandran plot analysis. Further, the model also has RMSD value 2.7 Angstrom which depicts the accuracy of predicted model. Study of surface topography for predicted 3-D model provided clue for interaction with inhibitor molecules to inhibit the virus activity. A computational screening protocol was used to identify small- 
<smiles>COc1c(C)c2c(c(O)c1C/C=C(\C)CCC(=O)O)C(=O)OC2</smiles>

446541 (Mycophenolate)

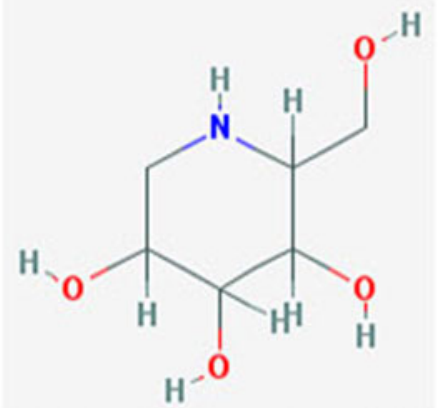

1374 (Deoxynojirimycin)

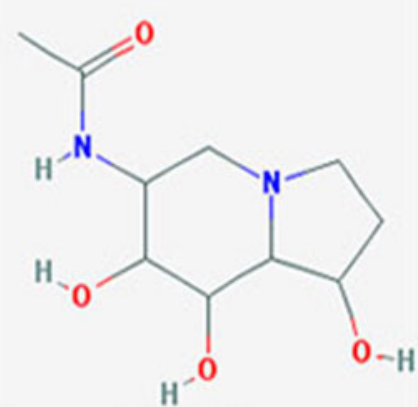

19978366 (Castanospermine)

Fig. 5 Structure of three best lead molecules with their compound IDs and name

Fig. 6 RMSD graph of E protein-mycophenolate complex

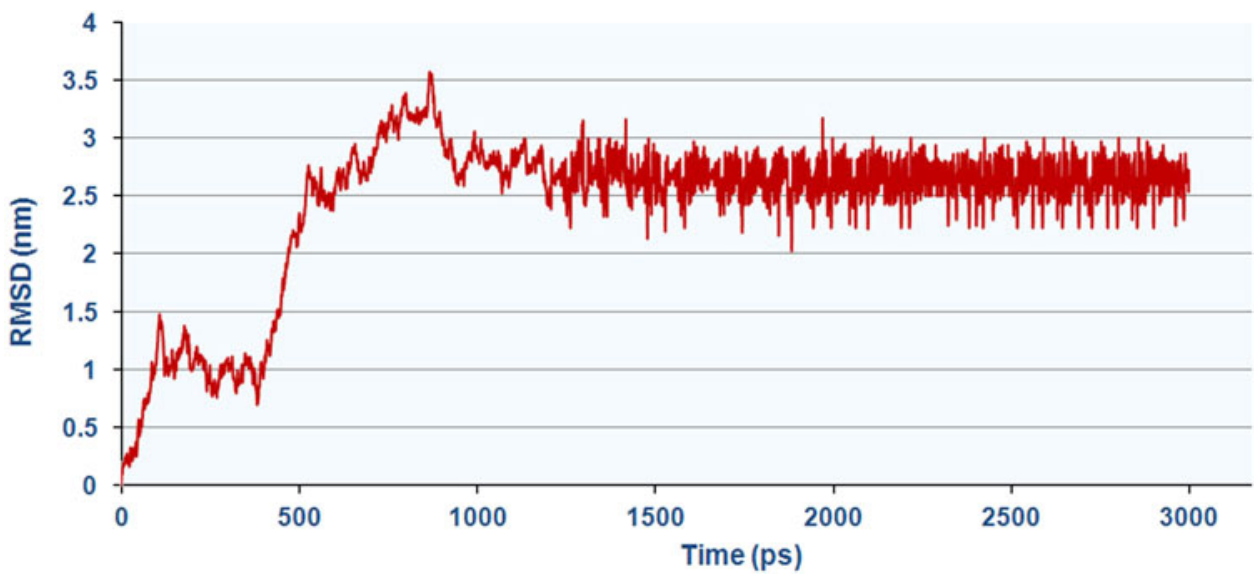

molecular compounds that bind to the active pocket of the $\mathrm{E}$ protein of JEV with the goal of identifying potential lead molecules. The screening was performed over more than one million molecules from PubChem compound database relying on computational docking and pharmacological properties prediction with Autodock 4.0 and OSIRIS Property Explorer, respectively. Through cautious visual inspection of the complexes binding mode and docking energy with the inhibitors of JEV E protein, the final three lead molecules were yielded. The comparatively less docking energy of the three lead molecules suggests these novel leads would potentially bind more strongly to active pocket of JEV E protein. Also, the three novel lead molecules have better pharmacological properties (low molecular weights 163-320 Da, no Lipinski rule of five violations, no reactive functional group, and low toxicity risk, i.e., mutagenic, tumerogenic, irritant and reproductive effective). The mycophenolate (CID 446541) showed best interaction with less docking energy and excellent pharmacological properties with JEV E protein. Thus, it is hoped that the mycophenolate newly identified lead molecule if synthesized and tested in animal models would hold promise for JEV drug discovery.

Acknowledgments We wish to thanks Biotech Park, Lucknow and King George's Medical University, Lucknow for providing workspace and also thanks to Indian Council of Medical Research, New Delhi for their support.

\section{References}

Altschul SF, Gish W, Miller W, Myers EW, Lipman DJ (1990) Basic local alignment search tool. J Mol Biol 215:403-410

Anwar R (2009) New tips for structure prediction by comparative modeling. Bioinformation 3(6):263-267

Castrignano T, de Meo PDO, Cozzetto D, Talamo IG, Tramontano A (2006) The PMDB Protein Model Database. Nucleic Acids Res 34:306-309

Christen M, Hunenberger PH, Bakowies D, Baron R, Burgi R (2005) The GROMOS software for biomolecular simulation: GROMOS05. J Comput Chem 26:1719-1751

Diagana M, Preux PM, Dumas M (2007) Japanese encephalitis revisited. J Neurol Sci 262(1-2):165-170

Dundas Joe, Ouyang Zheng, Tseng Jeffery, Binkowski Andrew, Turpaz Yaron, Liang Jie (2006) CASTp: computed atas of surface topography of proteins with structural and topographical mapping of functionally annotated residues. Nucl Acids Res 34:W116-W118

Eckert DM, Kim PS (2001) Design of potent inhibitors of HIV-1 entry from the gp41 N-peptide region. Proc Natl Acad Sci USA 98:11187-11192

Endy TP, Nisalak A (2002) Japanese encephalitis virus: ecology and epidemiology. Curr Top Microbiol Immunol 267:11-48

Eswar N, Eramian D, Webb B, Shen MY, Sali A (2008) Protein structure modeling with MODELLER. Methods Mol Biol 426:145-159 
Ghose AK, Viswanadhan VN, Wendoloski JJ (1999) A knowledgebased approach in designing combinatorial or medicinal chemistry libraries for drug discovery. 1. A qualitative and quantitative characterization of known drug databases. J Comb Chem 1:55-68

Guex N, Peitsch MC, Schwede T (2009) Automated comparative protein structure modeling with SWISS-MODEL and SwissPdbViewer: a historical perspective. Electrophoresis 30:S162S173

Gupta MK, Misra K (2013) Modeling and simulation analysis of propyl-thiouracil (PTU), an anti-thyroid drug on thyroid peroxidase (TPO), thyroid stimulating hormone receptor (TSHR), and sodium iodide (NIS) symporter based on systems biology approach. Netw Model Anal Health Inform Bioinforma 2:45-57

Hess B, Kutzner C, Spoel DV, Lindah E (2008) GROMACS 4: Algorithms for Highly Efficient, Load-Balanced, and Scalable Molecular Simulation. J Chem Theory Comput 4(3):435-447

Hrobowski YM, Garry RF, Michael SF (2005) Peptide inhibitors of dengue virus and West Nile virus infectivity. Virol J 1(2):49

Igarashi A, Tanaka M, Morita K et al (1994) Detection of West Nile and Japanese encephalitis viral genome sequences in cerebrospinal fluid from acute encephalitis cases in Karachi, Pakistan. Microbiol Immunol 38:827-830

Kanai R, Kar K, Anthony K, Gould LH, Ledizet M, Fikrig E, Marasco WA, Koski RA, Modis Y (2006) Crystal structure of West Nile virus envelope glycoprotein reveals viral surface epitopes. J Virol 80:11000-11008

Kilby JM, Hopkins S, Venetta TM, DiMassimo B, Cloud GA, Lee JY, Alldredge L, Hunter E, Lambert D, Bolognesi D, Matthews T, Johnson MR, Nowak MA, Shaw GM, Saag MS (1998) Potent suppression of HIV-1 replication in humans by T-20, a peptide inhibitor of gp41-mediated virus entry. Nat Med 4(11):1302-1307

Kimura M (1980) A simple method for estimating evolutionary rate of base substitution through comparative studies of nucleotide sequences. J Mol Evol 16:111-120

Kumar S, Tamura K, Jakobsen IB, Nei M (2001) MEGA2: molecular evolutionary genetics analysis software. Bioinformatics 17(12):1244-1245

Laskowski RA, MacAurther MW, Moss DS, Thornton JM (1993) Procheck- a program to check the stereo-chemical quality of protein structures. J Appl Crystallogr 26:47-60

Lindenbach B, Thiel H, Rice C (2007) Flaviviridae: the viruses and their replication. In: Knipe DM, Howley PM, Griffin DE, Lamb RA, Martin MA, Roizman B, Straus SE (eds) Fields virology, 5th edn. Lippincott Williams \& Wilkins, Philadelphia, pp 1101-1152

Luca VC, AbiMansour J, Nelson CA, Fremont DH (2012) Crystal structure of the Japanese encephalitis virus envelope protein. J Virol 86(4):2337-2346

Mackenzie JS, Johansen CA, Ritchie SA et al (2002) Japanese encephalitis as an emerging virus: the emergence and spread of Japanese encephalitis virus in Australasia. Curr Top Microbiol Immunol 267:49-73

Modis Y, Ogata S, Clements D, Harrison SC (2004) Structure of the dengue virus envelope protein after membrane fusion. Nature 427:313-319
Morris GM, Huey R, Lindstrom W, Sanner MF, Belew RK, Goodsell DS, Olson AJ (2009) Autodock4 and AutoDockTools4: automated docking with selective receptor flexibility. J Comput Chem 30(16):2785-2791

Nybakken GE, Nelson CA, Chen BR, Diamond MS, Fremont DH (2006) Crystal structure of the West Nile virus envelope glycoprotein. J Virol 80:11467-11474

Oprea TI, Davis AM, Teague SJ, Leeson PD (2001) Is there a difference between leads and drugs? A historical perspective. J Chem Inf Comput Sci 41(5):1308-1315

Rey FA, Heinz FX, Mandl C, Kunz C, Harrison SC (1995) The envelope glycoprotein from tick-borne encephalitis virus at $2 \AA$ resolution. Nature 375:291-298

Root MJ, Kay MS, Kim PS (2001) Protein design of an HIV-1 entry inhibitor. Science 291(5505):884-888

Sali A, Blundell TL (1993) Comparative protein modeling by satisfaction of spatial restraints. J Mol Biol 234:779-815

Schneidman-Duhovny D, Inbar Y, Nussinov R, Wolfson HJ (2005) PatchDock and SymmDock: servers for rigid and symmetric docking. Nucleic Acids Res 33:363-367

Shimojima M, Nagao Y, Shimoda H, Tamaru S, Yamanaka T, Matsumura T, Kondo T, Maeda K (2011) Full genome sequence and virulence analyses of the recent equine isolate of Japanese encephalitis virus. J Vet Med Sci 73(6):813-816

Singh DB, Gupta MK, Kesharwani RK, Misra K (2013) Comparative docking and ADMET study of some curcumin derivatives and herbal congeners targeting b-amyloid. Netw Model Anal Health Inform Bioinforma 2:13-27

Starr-Spires LD, Collman RG (2002) HIV-1 entry and entry inhibitors as therapeutic agents. Clin Lab Med 22(3):681-701

Stiasny K, Heinz FX (2006) Flavivirus membrane fusion. J Gen Virol $87: 2755-2766$

Thompson JD, Gibson TJ, Plewniak F, Jeanmougin F, Higgins DG (1997) The CLUSTAL X windows interface: flexible strategies for multiple sequence alignment aided by quality analysis tools. Nucleic Acids Res 25(24):4876-4882

Van den Hurk AF, Ritchie SA, Mackenzie JS (2009) Ecology and geographical expansion of Japanese encephalitis virus. Annu Rev Entomol 54:17-35

Vrati S (2000) Comparison of the genome sequences and the phylogenetic analyses of the GP78 and the Vellore P20778 isolates of Japanese encephalitis virus from India. J Biosci $25: 257-262$

Wallner B, Elofsson A (2003) Can correct protein models be identified? Protein Sci 12:1073-1086

Wiederstein M, Sippl MJ (2007) ProSA-web: interactive web service for the recognition of errors in threedimensional structures of proteins. Nucleic Acids Res 35:407-410

Yao Q, Compans RW (1996) Peptides corresponding to the heptad repeat sequence of human parainfluenza virus fusion protein are potent inhibitors of virus infection. Virology 223(1):103-112

Young JK, Hicks RP, Wright GE, Morrison TG (1997) Analysis of a peptide inhibitor of paramyxovirus (NDV) fusion using biological assays, NMR, and molecular modeling. Virology 238(2):291-304 